\title{
Anthropometric measurements of non- arthritic knees in an Egyptian population: an MRI-based study
}

\author{
Mohammad Kamal Abdelnasser ${ }^{1}$, Ahmed A. Khalifa ${ }^{2^{*}}$ (D), Micheal Bassem ${ }^{1}$, Mohammed Anter Abdelhameed ${ }^{1}$, \\ Mahmoud Faisal Adam', Hatem M. Bakr ${ }^{1}$ and Yaser E. Khalifa ${ }^{1}$
}

\begin{abstract}
Background: Knee anthropometric characteristics were evaluated for different ethnicities; however, data from North African populations are deficient. The primary aim was to investigate the Egyptian knees' anthropometric characteristics as a representative of North African populations. Secondary aims are as follows: (1) to study the anthropometric gender difference, (2) to compare results with other ethnic groups, and (3) to study the mismatch in comparison to geometric characteristics of modern TKA implant designs.
\end{abstract}

Methods: Two hundred normal knee MRI scans (100 females and 100 males, aging from 18 to 60) were obtained for analysis. Linear measurements (anteroposterior (AP), mediolateral (ML), and aspect ratio (AR)) of the planned cut surface of the distal femur ( $f$ ) and the proximal tibia ( $t$ ) were evaluated.

Results: A significant difference between both sexes was found, males had larger measurements in anteroposterior [fAP: $60.97 \pm 3.1$ vs $54.78 \pm 3.3(P<0.001)$, tAP: $46.89 \pm 3.0$ vs $41.35 \pm 2.9(P<0.001)$ ] and mediolateral [fML: $74.89 \pm$ 3.2 vs $67.29 \pm 3.7(P<0.001)$, tML: $76.01 \pm 3.0$ vs $67.26 \pm 3.2(P<0.001)$ ], the mean femoral and tibial AP and ML measurements were different from other ethnic groups. None of the seven studied TKA systems matched the largest ML or the smallest AP dimensions of the distal femur in the current study population.

Conclusion: A significant difference was found between males' and females' knee anthropometric characteristics. Some of the commonly used TKA implants in our area could not provide a perfect fit and coverage.

Trial registration: ClinicalTrials.gov identifier: NCT03622034, registered on July 28, 2018.

Keywords: Anthropometric, Total knee arthroplasty, Arab, North African

\section{Background}

Given the fact that total knee arthroplasty (TKA) is a highly successful procedure with documented success to relieve pain and improve motion in patients with endstage arthritis [1], however, a substantial number of patients are not satisfied after TKA [2], several factors are blamed [3, 4], of these, is the use of an appropriate

\footnotetext{
* Correspondence: ahmed_adel0391@med.svu.edu.eg

${ }^{2}$ Orthopaedic Department, Qena Faculty of Medicine and University Hospital, South Valley University, Qena, Egypt

Full list of author information is available at the end of the article
}

implant size which maximizes bony coverage and reduces overhang [5].

The different ethnicities' normal knee anthropometric data helped designing knee implants that provide the perfect size match with a consequent reduction in implant-sized mismatch-related complications [6-10]. Modern TKA prosthesis systems provide incremental femoral and tibial component sizes to offer the best fit for the replaced surface; however, most of these designs are based on measurements driven from white Western males [11-14]. Mahfouz et al. compared the non- 
arthritic knee anthropometric measurements between three different ethnicities (Asian, Caucasian, and African American) and found a significant difference in the knee dimensions [15]. A similar finding was reported in a systematic review by Kim et al. [16]. Further studies reported differences between various ethnic groups, including Caucasian [17], Indian [18], Thai [19], Korean [20], Chinese [21], Hispanic [22], and African Americans [15]. No similar studies existed for the Middle Eastern or African population [16].

Only one study by Hafez et al. [23] reported the anthropometric details of the Arabian knee; however, their study was based on arthritic knees, which may influence the accuracy of the measurements due to the presence of subchondral sclerosis, osteophytes, and bone attrition which may alter the normal anatomy of the knee, thereby changing the normal knee anthropometry [24].

This study's primary objective was to define the anthropometric measurements of the non-arthritic Egyptian knee (representing North African populations). The secondary objectives were (1) to study the anthropometric gender difference in our population, (2) to compare our results with other ethnic groups, and (3) to study the mismatch between the current study knee anthropometric values and the geometric characteristics of commonly used modern TKA implants.

\section{Methods}

This is a single-center observational cross-sectional study. Normal magnetic resonance imaging (MRI) scans (as reported by a senior radiologist) performed for patients with suspected knee ligamentous injury were used for analysis after our hospital's ethical committee's approval. Adult patients between 18 and 60 years were included. Knees where the MRI shows signs of osteoarthritis, gross bony, or cartilaginous defects were excluded. MRI of 100 males and 100 females was used for this study.

\section{Imaging technique}

A Siemens 1.5 Tesla magnet (Siemens, Erlangen, Germany) and a knee joint surface coil were used for examination. Images were taken at an intervening interval of $0.3 \mathrm{~mm}$ and a thickness of $3 \mathrm{~mm}$. To obtain an axial image parallel to knee joints, scans were performed while the patient was lying supine, and the knee was fully extended, keeping the patella towards the ceiling. The obtained images were processed via the local picture archiving and collecting system (PACS) used in our hospital, and the PACS software (Paxera Ultima 360) was used to do the measurements. To ensure the accuracy of the measurements, two of the authors measured each of the endpoints independently, and the average of both measurements was used for final analysis. Measurements were performed as follows:

\section{Distal femoral (f) measurement (Fig. 1)}

The trans-epicondylar axis (TEA) was first drawn as a line connecting the apexes of the medial and lateral femoral epicondyles in the widest axial cut of the distal femur (which contains the epicondyles) (Fig. 1a) [17]. The distal femoral measurements were done in the axial cut $9 \mathrm{~mm}$ above the most distal point of the medial femoral condyle to mimic the distal femoral cut in TKA as follows:

1) The femoral mediolateral ( $F M L)$ length was measured as the longest line connecting the medial and the lateral dimensions parallel to the transepicondylar axis (Fig. 1b).

2) The femoral anteroposterior (fAP) length: according to Kim et al. [16], there is no significant difference between Lateral femoral anteroposterior (fAP) length and the fAP length, so we considered the former as the AP femoral length. As the highest and the lowest points of the lateral distal femoral condyles (LDFC) could not be visualized in the same axial cut, so, we draw a line tangential to the lowest point of the lateral femoral condyle and parallel to the TEA in the corresponding axial cut (Line 1) (Fig. 1c). We reproduced line 1 in the axial cut that contains the highest point of the LDFC, and a second line tangential to the highest point and parallel to the TEA was drawn (Line 2). The vertical distance between Line 1 and Line 2 represents the fAP length (Fig. 1d).

3) The distal femur's aspect ratio (AR) was then calculated as (fML/fAP).

\section{Proximal Tibial (t) measurement (Fig. 2)}

The femoral TEA was reproduced in the tibial cuts. The proximal tibial measurements were performed in the axial cuts $8-9 \mathrm{~mm}$ distal to the joint surface (3 slices from the joint surface) as follows:

1) The tibial mediolateral (tML) length: it was measured as the longest mediolateral line (which is parallel to the TEA) in the axial cuts of the proximal tibia $[17,25,26]$.

2) The tibial anteroposterior (tAP) length: at the same level of the cuts, it was measured as the length of a line drawn perpendicular to the tML through the midpoint of the axial cut $(17,20,25)$.

3) The tibial $A R$ was calculated as (tML/tAP).

Anthropometric measurements of males and females from the current study were compared to detect gender 


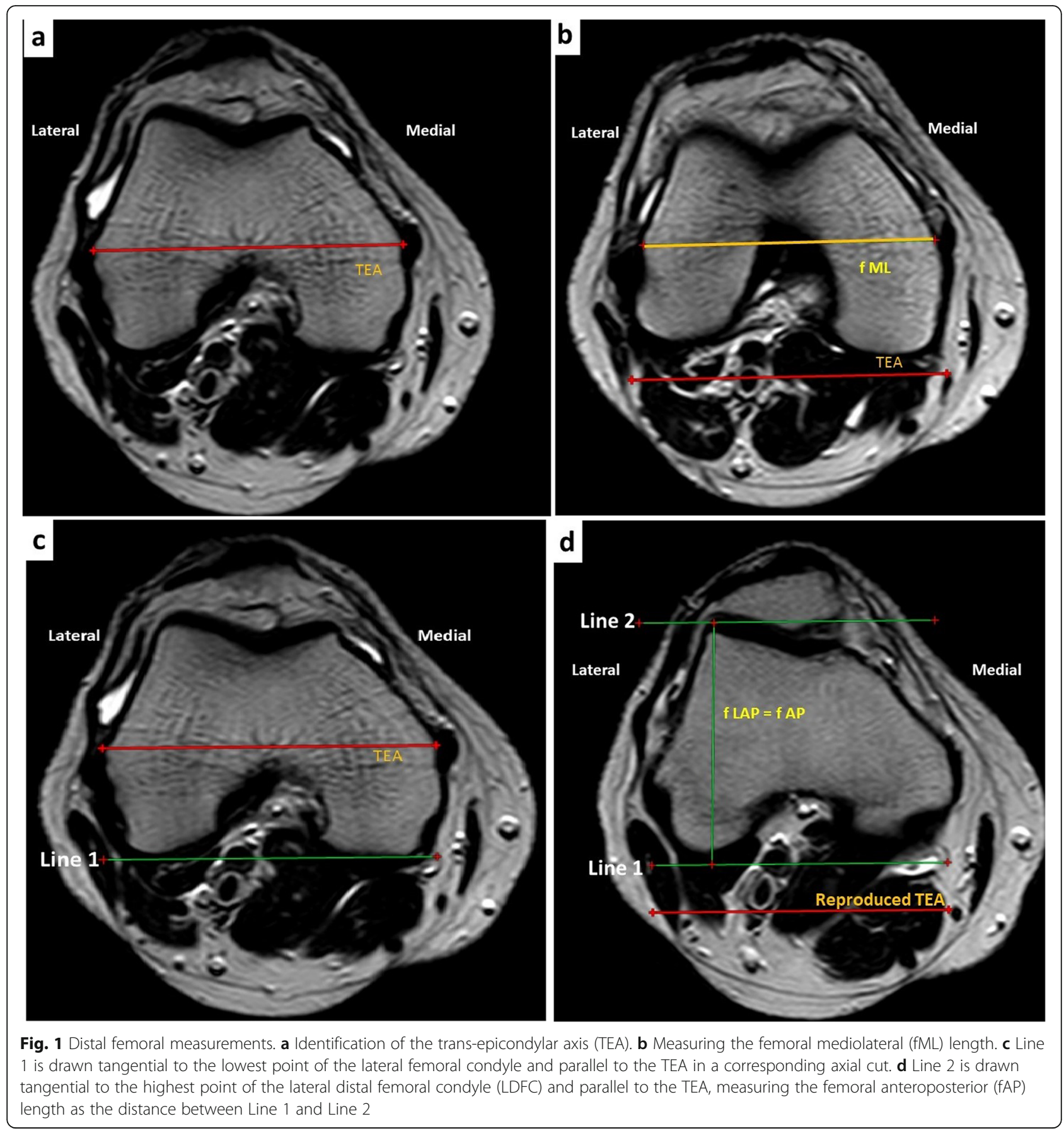

differences in the Egyptian population. These values were then compared with corresponding values for other ethnic groups and with geometric values for modern TKA implants and knee prostheses that are commonly used in Egypt.

Seven implant types were used for comparison. NexGen (Zimmer), PFC-Sigma (DePuy, J \& J), Scorpio PS (Stryker), Genesis 2, Journey 2, and Anthem (Smith \& Nephew), and Freedom (Maxx Health). The first three implants are widely used in our country. Scatter graphs were plotted with the patient size and the best possible implant size for all the implants.

\section{Statistical analysis}

Data were verified, coded by the researchers, and analyzed using SPSS (IBM_SPSS. Statistical Package for Social Science. Ver.21. Standard version. Copyright@ SPSS Inc., 2011-2012. NY, USA. 2012.). Descriptive statistics: 


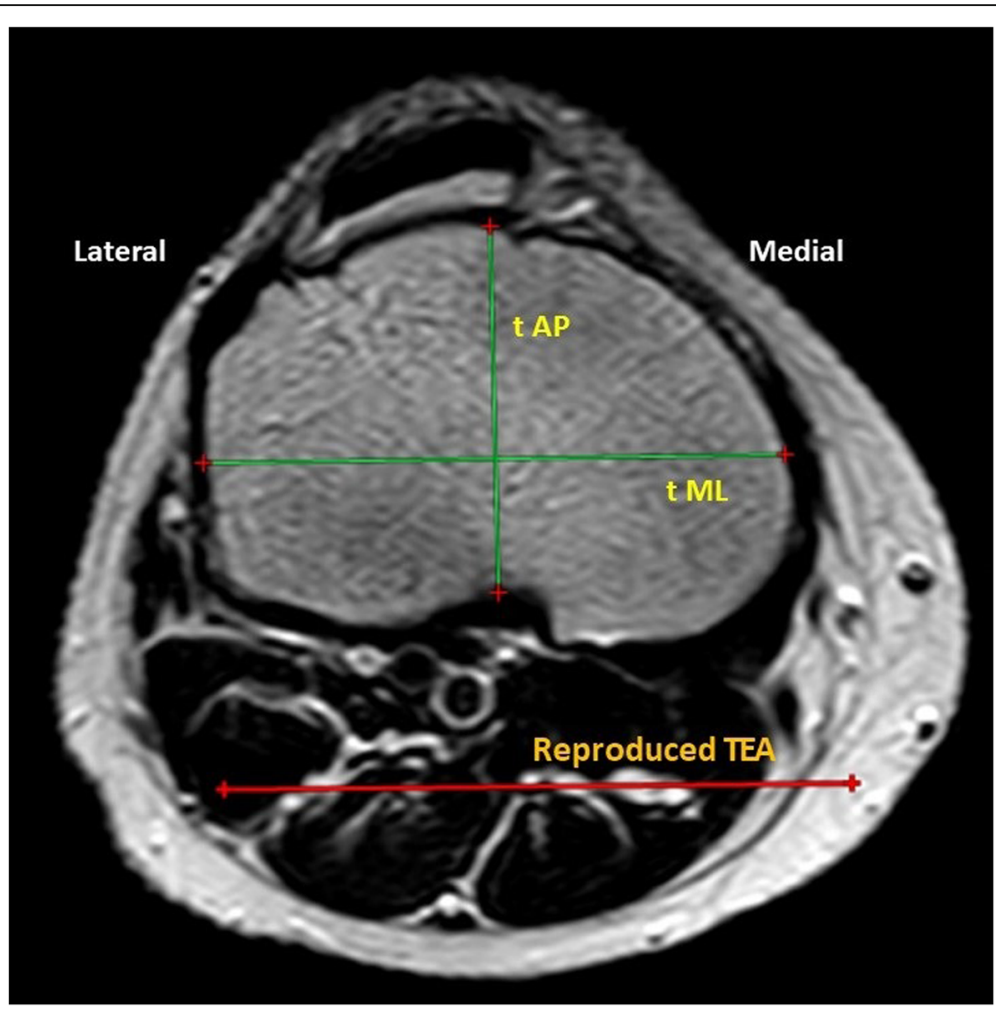

Fig. 2 Proximal tibial measurements: The tibial mediolateral (tML) length as the longest mediolateral diameter, the tibial anteroposterior (tAP) as the length of a line drawn perpendicular to the tML through the midpoint of the axial cut. (TEA, trans-epicondylar axis)

Means, standard deviations, and ranges were calculated. Intraclass Correlation Coefficient (ICC) was used to test the inter-rater reliability (ICC $>0.5$ is considered acceptable, $>0.6$ moderate, $>0.7$ good, $>0.8$ high, and $>0.9$ excellent). Test of significances: for continuous variables, a one-sample $t$ test was used to compare the mean of the study parameters against each of the other studies' single mean. Independent $t$ test analysis was carried out to compare the means of normally distributed data, while the Mann-Whitney $U$ test was calculated to test the median differences of the data that do not follow a normal distribution. A $p$ value $\leq 0.05$ was considered significant.

\section{Results}

The inter-rater agreement (ICC) for all measurements was $>0.8$. The study population's mean age was $34.16 \pm$ 11.24; there was no difference between males and females $(32.12 \pm 11.04$ and $36.21 \pm 11.11$, respectively). We found a significant difference between both sexes in the distal femoral and proximal tibial linear measurements where males had a significantly larger measurements in the anteroposterior [fAP: $60.97 \pm 3.1$ vs 54.78 $\pm 3.3(P<0.001)$, tAP: $46.89 \pm 3.0$ vs $41.35 \pm 2.9(P<$ $0.001)$ ] and mediolateral [fML: $74.89 \pm 3.2$ vs $67.29 \pm 3.7$ $(P<0.001)$, tML: $76.01 \pm 3.0$ vs $67.26 \pm 3.2(P<0.001)]$.
In contrast, the difference in the femoral and tibial aspect ratios was not significantly different, as shown in (Table 1).

\section{Comparing the measurement of the study population with measurements of other ethnic groups (Table 2) On the femoral side}

The mean AP measurement in our population was smaller than the American and Chinese and larger than the Thai, Hispanic, and Indians. No difference was found compared to the Caucasians. The mean ML measurement in our population was smaller than the Korean population, larger than the Thai and Indian, and no difference was found compared to the American, Chinese, Caucasians, and Hispanic measurements. The AR was smaller than American, Thai, Hispanic, and Indians, larger than Chinese, and not different from the Caucasians.

\section{On the tibial side}

The mean AP measurement was smaller than the Chinese, Thai, Caucasians, and Hispanic, with no difference from the Indians. The mean ML measurement was smaller than the Americans, Chinese, Caucasians, Hispanics, and Koreans but larger than the Thai and 
Table 1 Gender difference in anthropometric knee measurements (in $\mathrm{mm}$ )

\begin{tabular}{|c|c|c|c|c|}
\hline & Total $(n=200)$ & Female $(n=100)$ & Male $(n=100)$ & $P$ value* \\
\hline \multicolumn{5}{|c|}{ Tibial mediolateral (tML) } \\
\hline $\begin{array}{l}\text { Mean } \pm \text { SD } \\
\text { (Range) }\end{array}$ & $\begin{array}{l}71.62 \pm 5.4 \\
(61-83)\end{array}$ & $\begin{array}{l}67.26 \pm 3.2 \\
(61-77)\end{array}$ & $\begin{array}{l}76.01 \pm 3.0 \\
(68-83)\end{array}$ & $<0.001$ \\
\hline \multicolumn{5}{|c|}{ Tibial anteroposterior (tAP) } \\
\hline $\begin{array}{l}\text { Mean } \pm S D \\
\text { (Range) }\end{array}$ & $\begin{array}{l}44.14 \pm 4.0 \\
(36-54)\end{array}$ & $\begin{array}{l}41.35 \pm 2.9 \\
(36-48)\end{array}$ & $\begin{array}{l}46.89 \pm 3.0 \\
(41-54)\end{array}$ & $<0.001$ \\
\hline \multicolumn{5}{|c|}{ Femoral ,mediolateral (fML) } \\
\hline $\begin{array}{l}\text { Mean } \pm \text { SD } \\
\text { (Range) }\end{array}$ & $\begin{array}{l}71.09 \pm 5.1 \\
(59-85)\end{array}$ & $\begin{array}{l}67.29 \pm 3.7 \\
(59-78)\end{array}$ & $\begin{array}{l}74.89 \pm 3.2 \\
(66-85)\end{array}$ & $<0.001$ \\
\hline \multicolumn{5}{|c|}{ Femoral anteroposterior (fAP) } \\
\hline $\begin{array}{l}\text { Mean } \pm \text { SD } \\
\text { (Range) }\end{array}$ & $\begin{array}{l}57.88 \pm 4.4 \\
(42-68)\end{array}$ & $\begin{array}{l}54.78 \pm 3.3 \\
(42-65)\end{array}$ & $\begin{array}{l}60.97 \pm 3.1 \\
(53-68)\end{array}$ & $<0.001$ \\
\hline \multicolumn{5}{|c|}{ Femoral aspect ratio (fAR) } \\
\hline $\begin{array}{l}\text { Mean } \pm \text { SD } \\
\text { (Range) }\end{array}$ & $\begin{array}{l}1.23 \pm 0.07 \\
(1-1.5)\end{array}$ & $\begin{array}{l}1.23 \pm 0.08 \\
(1-1.5)\end{array}$ & $\begin{array}{l}1.23 \pm 0.06 \\
(1.1-1.5)\end{array}$ & $=0.650^{*}$ \\
\hline \multicolumn{5}{|c|}{ Tibial aspect ratio (tAR) } \\
\hline $\begin{array}{l}\text { Mean } \pm \text { SD } \\
\text { (Range) }\end{array}$ & $\begin{array}{l}1.63 \pm 0.09 \\
(1.3-1.9)\end{array}$ & $\begin{array}{l}1.63 \pm 0.09 \\
(1.3-1.9)\end{array}$ & $\begin{array}{l}1.62 \pm 0.09 \\
(1.5-1.8)\end{array}$ & $=0.932^{*}$ \\
\hline
\end{tabular}

*Student's $t$ test was used to compare the means among groups

Indians. The AR was larger than the Chinese, Caucasians, and Indians.

Comparing our results with Hafez et al. [23] study (Table 3) (where the population of the study came from the same geographic area as the population of the current study)

All the measurements in the current study were significantly smaller than what was reported in Hafez et al.'s study except for the tAR, which was greater in the current study.

\section{Comparing the measurement of the study population} with geometric characteristics of seven TKA implants The femoral and tibial AR of the current study population was higher than the femoral and tibial AR of all the implants used for comparison. This indicates a mismatch between the distal femoral and proximal tibial morphology and the sizes of the implants used in the comparison. For a given AP length, the implants' ML dimension was smaller than the ML diameter of the knee, which may lead to under coverage.

\section{Regarding femoral implants (Fig. 3)}

With respect to the distal femoral implant dimensions, none of the seven TKA systems matched the distal femur's largest ML dimension in the current study population. However, all seven implants matched the smallest ML knee diameter. All the seven TKA systems matched the largest AP dimension of the distal femur in the Egyptian populations. None of the seven TKA systems matched the distal femur's smallest AP dimension (which was present in the female group).

\section{Regarding tibial implants (Fig. 4)}

All the tibial implants could accommodate the ML dimensions of the proximal tibia in our population in the systems used for comparison; however, the smallest AP dimension (which was found in the female group) of the proximal tibia in the Egyptian population could not be matched with any of the seven TKA systems.

\section{Discussion}

The present study's important findings were that in the Egyptian population, females had knees with smaller AP and ML dimensions in both the distal femur and proximal tibia compared to males, most of the current study linear measurements were different from the data reported on the anthropometric measurements of the various ethnic groups used for comparison (reported in detail in Table 2), and the Egyptian knees had a different shape compared to the commonly used TKA implant designs, where the smallest sizes in the Egyptian females could not match with any of the seven TKA designs used for comparison, including the three designs most commonly used in Egypt. To the best of our knowledge, this is the first study to report the anthropometric data of non-arthritic knees from Middle Eastern and North African populations.

TKA surgery aims to restore the function and biomechanics of the normal native knee. To get the perfect implant fit, the sizing is considered for the femoral and 
Table 2 Summary of the morphometry of the proximal tibia and distal femur (in $\mathrm{mm}$ ) in various studies

\begin{tabular}{|c|c|c|c|c|c|c|c|c|c|}
\hline \multirow[b]{2}{*}{ Authors } & \multirow[b]{2}{*}{ Population } & \multirow[b]{2}{*}{ Method } & \multirow[b]{2}{*}{ Study No. } & \multicolumn{3}{|c|}{$\begin{array}{l}\text { (Morphometry of the } \\
\text { proximal tibia) }\end{array}$} & \multicolumn{3}{|c|}{$\begin{array}{l}\text { (Morphometry of the distal } \\
\text { femur) }\end{array}$} \\
\hline & & & & $\mathrm{t}-\mathrm{ML}$ & t-AP & t-AR & f-ML & f-AP & f-AR \\
\hline Mensch et al. [12] I & American & Radiograph & $\begin{array}{l}30 \text { cadavers } \\
53 \\
\text { radiographic } \\
\text { knees }\end{array}$ & $\begin{array}{l}80.3 \pm \\
3.7(\mathrm{M}) \\
70.1 \pm \\
2.8(\mathrm{~F}) \\
74.9 \pm \\
6.1(\mathrm{C})\end{array}$ & NR & NR & $\begin{array}{l}78.5 \pm \\
7.1(\mathrm{M}) \\
70.5 \pm \\
5.5(\mathrm{~F}) \\
72.1 \pm \\
6.6(\mathrm{C})\end{array}$ & $\begin{array}{l}78.5 \pm \\
4.7(\mathrm{M}) \\
67.3 \pm \\
4.9(\mathrm{~F}) \\
68.4 \pm \\
6.9(\mathrm{C})\end{array}$ & $\begin{array}{l}1.44 \pm \\
0.1(\mathrm{M}) \\
1.43 \pm \\
0.1(\mathrm{~F}) \\
1.43 \pm \\
0.1(\mathrm{C})\end{array}$ \\
\hline Cheng et al. [19] ॥ & Chinese & CT & $\begin{array}{l}172 \\
\text { non-arthritic }\end{array}$ & $\begin{array}{l}76.4 \pm \\
2.8(\mathrm{M}) \\
68.8 \pm \\
4.6(\mathrm{~F}) \\
73.0 \pm \\
4.6(\mathrm{C})\end{array}$ & $\begin{array}{l}51.3 \pm \\
2.0(\mathrm{M}) \\
45.7 \pm \\
1.9(\mathrm{~F}) \\
48.8 \pm \\
3.4(\mathrm{C})\end{array}$ & $\begin{array}{l}1.49 \pm \\
0.05(\mathrm{M}) \\
1.51 \pm \\
0.06(\mathrm{~F}) \\
1.50 \pm \\
0.05(\mathrm{C})\end{array}$ & $\begin{array}{l}74.4 \pm \\
2.9(\mathrm{M}) \\
66.8 \pm \\
3.1(\mathrm{~F}) \\
71.0 \pm \\
3.0(\mathrm{C})\end{array}$ & $\begin{array}{l}66.6 \pm \\
2.4(\mathrm{M}) \\
61.0 \pm \\
2.7(\mathrm{~F}) \\
64.1 \pm \\
2.7(\mathrm{C})\end{array}$ & $\begin{array}{l}1.12 \pm \\
0.03(\mathrm{M}) \\
1.10 \pm \\
0.02(\mathrm{~F}) \\
1.11 \pm \\
0.3(\mathrm{C})\end{array}$ \\
\hline Chaichankul et al. [17] III & Thai & MRI & $\begin{array}{l}200 \\
\text { non-arthritic }\end{array}$ & $\begin{array}{l}74.4 \pm \\
3.4(\mathrm{M}) \\
64.9 \pm \\
3.5(\mathrm{~F}) \\
68.8 \pm \\
5.8(\mathrm{C})\end{array}$ & $\begin{array}{l}50.2 \pm \\
3.1(\mathrm{M}) \\
43.2 \pm \\
2.6(\mathrm{~F}) \\
46.1 \pm \\
4.4(\mathrm{C})\end{array}$ & NR & $\begin{array}{l}70.2 \pm \\
3.9(\mathrm{M}) \\
59.9 \pm \\
3.8(\mathrm{~F}) \\
65.05 \pm \\
3.85(\mathrm{C})\end{array}$ & $\begin{array}{l}48.6 \pm \\
3.7(\mathrm{M}) \\
43.3 \pm \\
3.7(\mathrm{~F}) \\
45.95 \pm \\
3.7(\mathrm{C})\end{array}$ & $\begin{array}{l}1.45 \pm \\
0.1(\mathrm{M}) \\
1.39 \pm \\
0.1(\mathrm{~F}) \\
1.42 \pm \\
0.1(\mathrm{C})\end{array}$ \\
\hline Li et al. [15] IV & Caucasian & CT & $\begin{array}{l}127 \\
\text { non-arthritic }\end{array}$ & $\begin{array}{l}79.4 \pm \\
4.3(\mathrm{M}) \\
70.2 \pm \\
2.7(\mathrm{~F}) \\
74.8 \\
3.5(\mathrm{C})\end{array}$ & $\begin{array}{l}49.5 \pm \\
2.9(\mathrm{M}) \\
45.2 \pm \\
2.3(\mathrm{~F}) \\
47.4 \pm \\
2.6(\mathrm{C})\end{array}$ & $\begin{array}{l}1.61 \pm \\
0.1(\mathrm{M}) \\
1.54 \pm \\
0.1(\mathrm{~F}) \\
1.6 \pm \\
0.1(\mathrm{C})\end{array}$ & $\begin{array}{l}74.6 \pm \\
3.9(\mathrm{M}) \\
65.4 \pm \\
1.4(\mathrm{~F}) \\
70 \pm \\
2.65(\mathrm{C})\end{array}$ & $\begin{array}{l}59.6 \pm \\
3.2(\mathrm{M}) \\
55.4 \pm \\
2.8(\mathrm{~F}) \\
57.5 \pm \\
3(\mathrm{C})\end{array}$ & $\begin{array}{l}1.25 \pm \\
0.1(\mathrm{M}) \\
1.18 \pm \\
0.1(\mathrm{~F}) \\
1.22 \pm \\
0.1(\mathrm{C})\end{array}$ \\
\hline Mcnamara et al. [20] V & Hispanic & MRI & $\begin{array}{l}500 \\
\text { non-arthritic }\end{array}$ & $\begin{array}{l}80.3 \pm \\
4.0(\mathrm{M}) \\
69.8 \pm \\
3.1(\mathrm{~F}) \\
75.1 \pm \\
3.6(\mathrm{C})\end{array}$ & $\begin{array}{l}54.7 \pm \\
3.3(\mathrm{M}) \\
47.1 \pm \\
2.6(\mathrm{~F}) \\
50.9 \pm \\
3(\mathrm{C})\end{array}$ & NR & $\begin{array}{l}77.2 \pm \\
4.1(\mathrm{M}) \\
66.3 \pm \\
3.0(\mathrm{~F}) \\
71.8 \pm \\
3.55(\mathrm{C})\end{array}$ & $\begin{array}{l}49.9 \pm \\
3.8(\mathrm{M}) \\
45.6 \pm \\
3.2(\mathrm{~F}) \\
47.75 \pm \\
3.5(\mathrm{C})\end{array}$ & $\begin{array}{l}1.55 \pm \\
0.1(\mathrm{M}) \\
1.46 \pm \\
0.1(\mathrm{~F}) \\
1.51 \pm \\
0.1(\mathrm{C})\end{array}$ \\
\hline Mohan et al. [16] Vl & Indian & MRI & $\begin{array}{l}100 \\
\text { non-arthritic }\end{array}$ & $\begin{array}{l}75.7 \pm \\
4.3(\mathrm{M}) \\
65.5 \pm \\
3.2(\mathrm{~F}) \\
70.6 \pm \\
3.8(\mathrm{C})\end{array}$ & $\begin{array}{l}49.1 \pm \\
3.9(\mathrm{M}) \\
43.3 \pm \\
2.7(\mathrm{~F}) \\
46.2 \pm \\
3.3(\mathrm{C})\end{array}$ & $\begin{array}{l}1.55 \pm \\
0.1(\mathrm{M}) \\
1.52 \pm \\
0.07(\mathrm{~F}) \\
1.54 \pm \\
0.09(\mathrm{C})\end{array}$ & $\begin{array}{l}73.7 \pm \\
4.1(\mathrm{M}) \\
64.8 \pm \\
3.4(\mathrm{~F}) \\
69.3 \pm \\
3.8(\mathrm{C})\end{array}$ & $\begin{array}{l}57.5 \pm \\
3.1(\mathrm{M}) \\
52.8 \pm \\
3.1(\mathrm{~F}) \\
55.2 \pm \\
3.1(\mathrm{C})\end{array}$ & $\begin{array}{l}1.28 \pm \\
0.1(\mathrm{M}) \\
1.23 \pm \\
0.1(\mathrm{~F}) \\
1.26 \pm \\
0.1(\mathrm{C})\end{array}$ \\
\hline Lim et al. [18] VII & Korean & MRI & $\begin{array}{l}115 \\
\text { non-arthritic }\end{array}$ & $\begin{array}{l}80.6 \pm \\
6.3(\mathrm{M}) \\
70.0 \pm \\
3.5(\mathrm{~F}) \\
75.3 \pm \\
4.9(\mathrm{C})\end{array}$ & $N R$ & NR & $\begin{array}{l}81.5 \pm 5.7 \\
(M) \\
76.7 \pm 3.7 \\
(F) \\
79.1 \pm \\
4.7(C)\end{array}$ & $N R$ & $N R$ \\
\hline Our Study VIII & Egyptian & MRI & $\begin{array}{l}200 \\
\text { non-arthritic }\end{array}$ & $\begin{array}{l}76.1 \pm \\
3.0(\mathrm{M}) \\
67.3 \pm \\
3.2(\mathrm{~F}) \\
71.6 \pm \\
5.4(\mathrm{C})\end{array}$ & $\begin{array}{l}46.9 \pm \\
3.0(\mathrm{M}) \\
41.4 \pm \\
2.9(\mathrm{~F}) \\
44.2 \pm \\
4.0(\mathrm{C})\end{array}$ & $\begin{array}{l}1.62 \pm \\
0.1(\mathrm{M}) \\
1.63 \pm \\
0.1(\mathrm{~F}) \\
1.63 \pm \\
0.1(\mathrm{C})\end{array}$ & $\begin{array}{l}74.9 \pm \\
3.2(\mathrm{M}) \\
67.3 \pm \\
3.7(\mathrm{~F}) \\
71.1 \pm \\
5.1(\mathrm{C})\end{array}$ & $\begin{array}{l}61.0 \pm \\
3.1(\mathrm{M}) \\
54.8 \pm \\
3.3(\mathrm{~F}) \\
57.9 \pm \\
4.4(\mathrm{C})\end{array}$ & $\begin{array}{l}1.23 \pm \\
0.01(\mathrm{M}) \\
1.23 \pm \\
0.02(\mathrm{~F}) \\
1.23 \pm \\
0.04(\mathrm{C})\end{array}$ \\
\hline \multirow{7}{*}{$\begin{array}{l}\text { Comparing the results from previous } \\
\text { studies with our results. * }\end{array}$} & VIII vs. I & & & $<0.001$ & & & $=0.013$ & $<0.001$ & $<0.001$ \\
\hline & VIII vs. II & & & $<0.001$ & $<0.001$ & $<0.001$ & $=0.810$ & $<0.001$ & $<0.001$ \\
\hline & VIII vs. III & & & $<0.001$ & $<0.001$ & & $<0.001$ & $<0.001$ & $<0.001$ \\
\hline & VIII vs. IV & & & $<0.001$ & $<0.001$ & $<0.001$ & $=0.003$ & $=0.228$ & $=0.002$ \\
\hline & VIII vs. V & & & $<0.001$ & $<0.001$ & & $=0.052$ & $<0.001$ & $<0.001$ \\
\hline & VIII vs. VI & & & $<0.001$ & $=0.163$ & $<0.001$ & $<0.001$ & $<0.001$ & $<0.001$ \\
\hline & VIII vs. VII & & & $<0.001$ & & & $<0.001$ & & \\
\hline
\end{tabular}


Table 3 Comparison of the current study with Hafez et al.

\begin{tabular}{|c|c|c|c|c|c|c|c|c|c|}
\hline \multirow[b]{2}{*}{ Authors } & \multirow[b]{2}{*}{ Population } & \multirow[b]{2}{*}{ Method } & \multirow[b]{2}{*}{$\begin{array}{l}\text { Study knee } \\
\text { No. }\end{array}$} & \multicolumn{3}{|c|}{ (Morphometry of the proximal tibia) } & \multicolumn{3}{|c|}{ (Morphometry of the distal femur) } \\
\hline & & & & $\mathrm{t}-\mathrm{ML}$ & t-AP & $t-A R$ & f-ML & f-AP & $f-A R$ \\
\hline $\begin{array}{l}\text { Hafez et al. } \\
\text { [21] }\end{array}$ & Arabian & $3 \mathrm{D} C \mathrm{~T}$ & $\begin{array}{l}124 \\
\text { (arthritic) }\end{array}$ & $\begin{array}{l}80.2 \pm 4.6 \\
(\mathrm{M}) \\
72.9 \pm 5.5(\mathrm{~F}) \\
74.4 \pm 6.0(\mathrm{C})\end{array}$ & $\begin{array}{l}52.5 \pm 5.6 \\
(\mathrm{M}) \\
48.1 \pm 3.9(\mathrm{~F}) \\
48.9 \pm 4.6(\mathrm{C})\end{array}$ & $\begin{array}{l}1.56 \pm 0.1 \\
(\mathrm{M}) \\
1.52 \pm 0.1(\mathrm{~F}) \\
1.53 \pm 0.1(\mathrm{C})\end{array}$ & $\begin{array}{l}78.5 \pm 7.1 \\
(\mathrm{M}) \\
70.5 \pm 5.5(\mathrm{~F}) \\
72.1 \pm 6.6(\mathrm{C})\end{array}$ & $\begin{array}{l}78.5 \pm 4.7 \\
(\mathrm{M}) \\
67.3 \pm 4.9(\mathrm{~F}) \\
68.4 \pm 6.9(\mathrm{C})\end{array}$ & $\begin{array}{l}1.43 \pm 0.1(\mathrm{M}) \\
1.42 \pm 0.1(\mathrm{~F}) \\
1.43 \pm 0.1(\mathrm{C})\end{array}$ \\
\hline Our study & Egyptian & MRI & $\begin{array}{l}200 \\
\text { (non-arthritic) }\end{array}$ & $\begin{array}{l}76.1 \pm 3.0 \\
(\mathrm{M}) \\
67.3 \pm 3.2(\mathrm{~F}) \\
71.6 \pm 5.4(\mathrm{C})\end{array}$ & $\begin{array}{l}46.9 \pm 3.0 \\
(\mathrm{M}) \\
41.4 \pm 2.9(\mathrm{~F}) \\
44.2 \pm 4.0(\mathrm{C})\end{array}$ & $\begin{array}{l}1.62 \pm 0.1 \\
(\mathrm{M}) \\
1.63 \pm 0.1(\mathrm{~F}) \\
1.63 \pm 0.1(\mathrm{C})\end{array}$ & $\begin{array}{l}74.9 \pm 3.2 \\
(\mathrm{M}) \\
67.3 \pm 3.7(\mathrm{~F}) \\
71.1 \pm 5.1(\mathrm{C})\end{array}$ & $\begin{array}{l}61.0 \pm 3.1 \\
(\mathrm{M}) \\
54.8 \pm 3.3(\mathrm{~F}) \\
57.9 \pm 4.4(\mathrm{C})\end{array}$ & $\begin{array}{l}1.23 \pm 0.01 \\
(\mathrm{M}) \\
1.23 \pm 0.02(\mathrm{~F}) \\
1.23 \pm 0.04(\mathrm{C}\end{array}$ \\
\hline$P$ value & & & & $<0.001^{*}$ & $<0.001^{*}$ & $<0.001^{*}$ & $<0.001^{*}$ & $<0.001^{*}$ & $<0.001^{*}$ \\
\hline
\end{tabular}

$M$ male, $F$ female, $C$ combined

*One sample $t$ test was used to compare the study mean vs the mean of other studies

tibial components only after removing any osteophytes to reach the bony limits of the native knee [18]. To get accurate anthropometric data, the measurements should be performed on a normal knee model (either radiographic, CT, or MRI), as the arthritis process alters the anatomic dimensions [24]. In the current study, we used MRI scans to obtain the desired measurements; this technique was used by most previous studies reporting anthropometric knee evaluation [18-20, 22], as the values measured by MRI were reported to equal those measured intraoperatively by direct methods [27]. Moreover, MRI accounts for cartilage thickness, which corresponds to sizing techniques in most TKA systems [18].

The only study we could find reporting the measurement of an Arab population (which is similar to the current study population) was by Hafez et al. [23], where they reported the anthropometry of the arthritic Arabian knee by evaluating 126 CT scans. In concordance with our study, Hafez et al. found that ML and AP dimensions of the proximal tibia were significantly smaller in females than males. However, the measurements reported by Hafez et al.'s study were significantly larger than the current study except for the tAR. Although they subtracted the osteophytes from the measurements; still the presence of subchondral sclerosis and chondrocalcinosis alter the normal anatomy, thereby altering the normal knee anthropometry, which may affect the reliability of the measurements [24].

Some studies stressed the importance of matching TKA implant sizes and the native bony surfaces, both in the femur and the tibia, as adverse effects may result from unattended mismatch $[28,29]$. Hitt et al. reported that lateral or medial overhang of the femoral or tibial implants could lead to soft tissue irritation, which may affect the soft tissue balance and be a source of chronic pain [30].

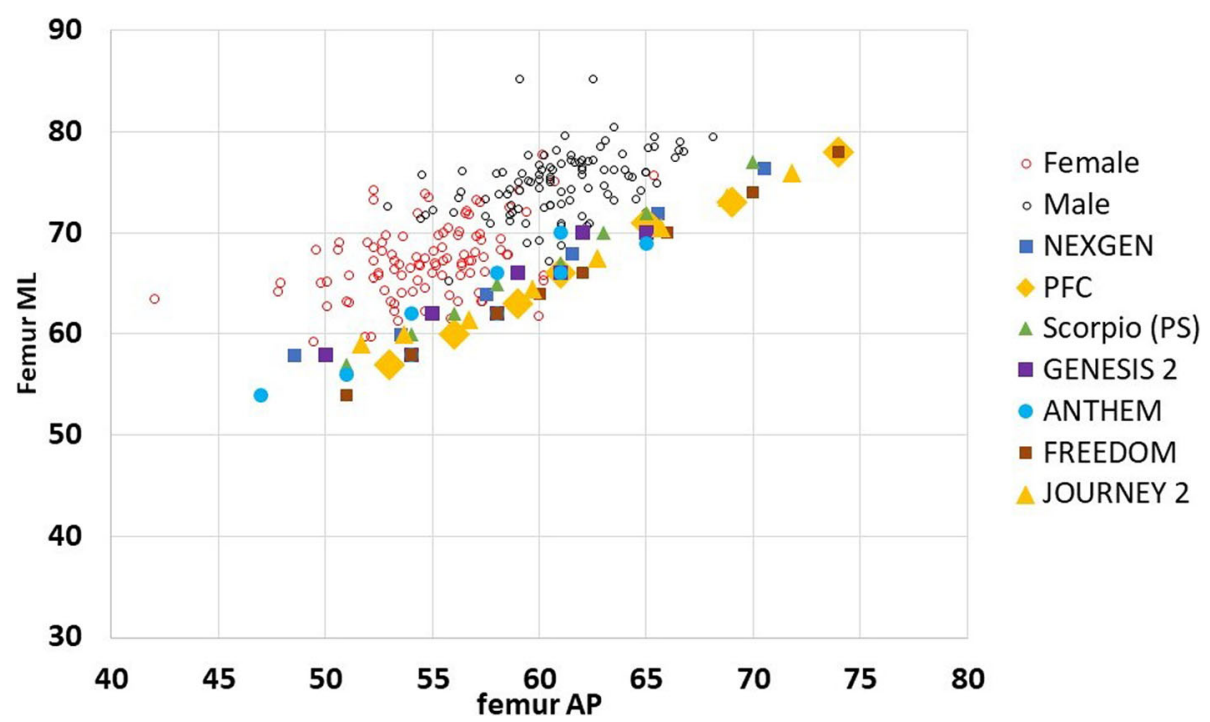

Fig. 3 Graph showing correlations between the femoral anthropometric measurements and modern knee implant designs (fML, femoral mediolateral; fAP, femoral anteroposterior) 


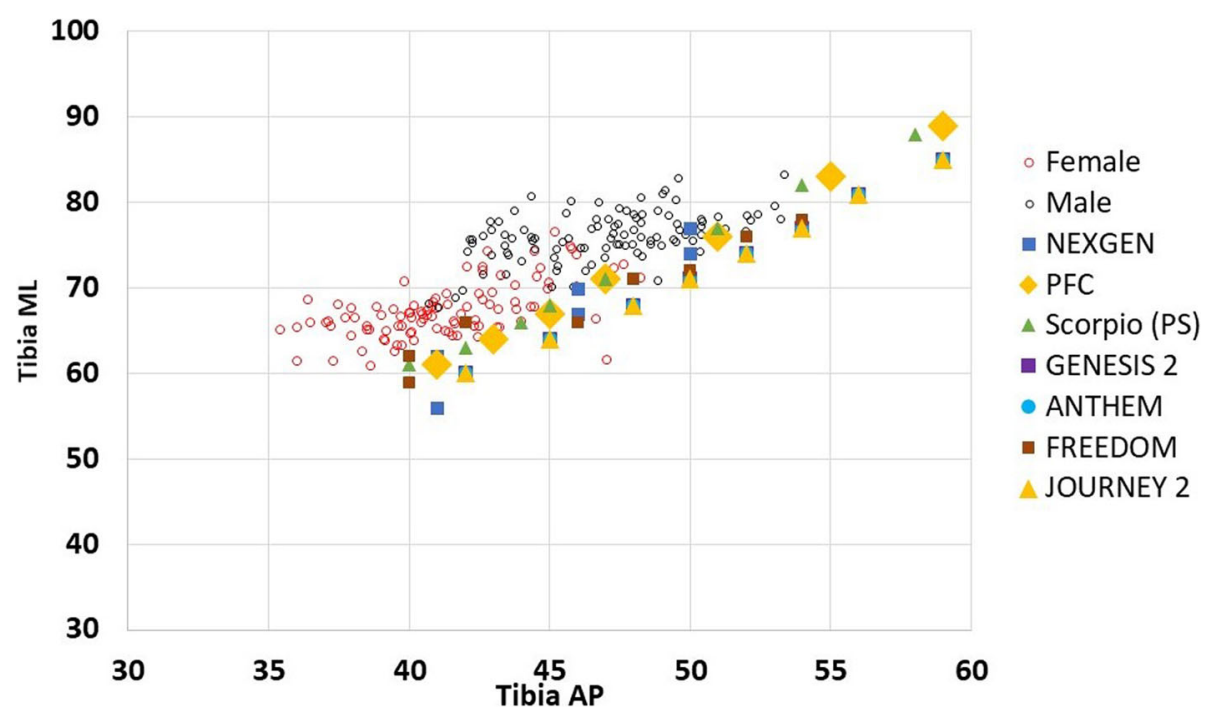

Fig. 4 Graph showing correlations between the tibial anthropometric measurements and modern knee implant designs (tAP, tibial anteroposterior; $\mathrm{tML}$, tibial mediolateral)

In the current study, we found that the AR (femoral and tibial) of both males and females are larger than all of the implants used for the comparison indicating that for a given AP dimension, the ML measurements in our population will be larger than that of the implant which will lead to the problem of under-coverage, to get a proper ML fit in our population the proper choice will be of an implant with a wider ML dimension, which if used from the current TKA implant designs will lead to increase in the AP dimension as well and subsequent overstuffing of the patellofemoral joint [31,32].

Regarding the matching between the implants used for comparison and the anthropometric measurements of the current study, for the femoral component sizes, we identified subsets of Egyptians (especially females) with a small fAP diameter that the smallest TKA systems could not accommodate; however, in males, although the TKA designs covered all the AP diameters, males' femurs tended to be wider (larger ML diameter) than most components for a given AP size, which may lead to the problem of under coverage [33]. For the tibial component sizes, the tibias measured from Egyptian males matches well with the implants included in the comparison; however, in females, we found a subset with a small tAP diameter than all the tibial implants included in the comparison, which leads to the problem of tibial implant impingement on the posterior soft tissue structures [34].

The current study has some limitations; first, the study population came from a narrow geographical area, making the generalization of the results over other populations in our area difficult. Second, the measurements were taken on an ideal scenario tibial and femoral cuts; this may be untrue in real life in patients with severe deformities where the surgeon may have to take a bigger cut than the usually performed for straightforward cases; however, we believe that the measurements taken from normal knees should act as the foundation for designing newer implants for our population and the surgeon should take into his account the issue of extra bony cuts in cases with severe deformity during the pre-operative planning. Third, the study population's weight and height were not included in the analysis, which may correlate with the distal femur's dimensions and the proximal tibia. Fourth, measurements were driven from MRI images, which had been criticized for not showing a three-dimensional shape of knee joints, which may increase the incidence of AP and ML measurement errors; however, the method we used in the current study had been well documented and reported in previous studies handling the same issue. Last, comparing the results obtained from the current study with previous studies reported in the literature may be criticized for being unrealistic due to differences in measurement techniques, type of imaging modalities, and the state of the knee being arthritic or normal.

\section{Future perspectives}

Further multicenter studies from different populations with larger numbers in our area are highly recommended; studies evaluating the possible effects of implants mismatch on the clinical outcomes are mandatory to back up the present finding aiming at providing special implants sizes according to various populations anthropometric measurements, and a discussion should be 
initiated with the manufacturers to take these studies and their findings in consideration when designing new implants.

\section{Conclusion}

There is a significant difference in the knee anthropometric characteristics between males and females in our population, and some of the commonly used TKA implants in our area may not produce a perfect fit if used in our population. The current study results can provide insight for surgeons operating on knees from the same population of our study to select the most appropriate knee designs that will provide appropriate fit and coverage.

\section{Abbreviations}

AP: Anteroposterior; ML: Mediolateral; AR: Aspect ratio; TKA: total knee arthroplasty; MRI: Magnetic resonance imaging; PACS: Picture archiving and collecting system; f: Femoral; TEA: Trans-epicondylar axis; fML: Femoral mediolateral; fAP: Femoral anteroposterior; LDFC: Lateral distal femoral condyles; t: Tibial; tML: Tibial mediolateral; tAP: Tibial anteroposterior; ICC: Intraclass Correlation Coefficient

\section{Acknowledgements}

We would like to thank the radiology department staff in our hospital to follow the MRI protocol for the patients and assist in collecting the images

\section{Authors' contributions}

YK and MKA carried out the Study conception and design and performed the surgeries; MB, MAA, and MFA carried out data acquisition and measurements. MKA, AAK, and $\mathrm{HMB}$ carried out analysis and interpretation of data, drafted the manuscript, and designed the figures and tables; YK and HMB did the critical revision. All authors discussed the results and commented on the manuscript. All authors read and approved the final manuscript. Both the first and the second authors contributed equally to the manuscript.

\section{Funding}

This research did not receive any specific grant from funding agencies in the public, commercial, or not-for-profit sectors.

\section{Availability of data and materials}

All the data and materials were included within the manuscript.

\section{Declarations}

\section{Ethics approval and consent to participate}

This article does not contain any experimental studies with human participants or animals performed by any of the authors, and the ethical committee of our institution approved it: Faculty of Medicine, Assiut University, Egypt (IRB no.: 17100554) (Telephone, Fax: +20882332278, ethicscommittee12@yahoo.com, http://afm.edu.eg), Clinical Trials.gov identifier: NCT03622034. Consent to participate was obtained from all patients to use their radiographs for this research.

\section{Competing interests}

The authors declare that they have no competing interests.

\section{Author details}

'Orthopaedic and Traumatology Department, Assiut University Hospital, Assiut, Egypt. ${ }^{2}$ Orthopaedic Department, Qena Faculty of Medicine and University Hospital, South Valley University, Qena, Egypt.
Received: 31 July 2021 Accepted: 31 August 2021

Published online: 08 September 2021

\section{References}

1. Ethgen O, Bruyere O, Richy F, Dardennes C, Reginster JY. Health-related quality of life in total hip and total knee arthroplasty. A qualitative and systematic review of the literature. J Bone Joint Surg Am. 2004;86(5):963-74. https://doi.org/10.2106/00004623-200405000-00012.

2. Bourne RB, Chesworth BM, Davis AM, Mahomed NN, Charron KD. Patient satisfaction after total knee arthroplasty: who is satisfied and who is not? Clin Orthop Relat Res. 2010;468(1):57-63. https://doi.org/10.1007/s11999009-1119-9.

3. Choong PF, Dowsey MM, Stoney JD. Does accurate anatomical alignment result in better function and quality of life? Comparing conventional and computer-assisted total knee arthroplasty. J Arthroplast. 2009;24(4):560-9. https://doi.org/10.1016/j.arth.2008.02.018.

4. Abdelnasser MK, Elsherif ME, Bakr H, Mahran M, Othman MH, Khalifa Y. All types of component malrotation affect the early patient-reported outcome measures after total knee arthroplasty. Knee Surg Relat Res. 2019;31(1):5. https://doi.org/10.1186/s43019-019-0006-2.

5. Han H, Oh S, Chang CB, Kang SB. Anthropometric difference of the knee on MRI according to gender and age groups. Surg Radiol Anat. 2016;38(2):20311. https://doi.org/10.1007/s00276-015-1536-2.

6. Bellemans J, Carpentier K, Vandenneucker H, Vanlauwe J, Victor J. The John Insall award: both morphotype and gender influence the shape of the knee in patients undergoing TKA. Clin Orthop Relat Res. 2010;468(1):29.

7. Gaillard R, Bankhead C, Budhiparama N, Batailler C, Servien E, Lustig S. Influence of patella height on Total knee Arthroplasty: outcomes and survival. J Arthroplast. 2019;34(3):469-77. https:/doi.org/10.1016/j.arth.2018.10.037.

8. Yang B, Song CH, Yu JK, Yang YQ, Gong X, Chen LX, et al. Intraoperative anthropometric measurements of tibial morphology: comparisons with the dimensions of current tibial implants. Knee Surg Sports Traumatol Arthrosc. 2014:22(12):2924-30. https://doi.org/10.1007/s00167-014-3258-0.

9. Nair VS, Radhamony NG, Padmalayam A, Govindan NO. Anthropometric comparison between Indian and Arabian knees with respect to Total knee replacement. J Knee Surg. 2020. https://pubmed.ncbi.nlm.nih.gov/32838458/, https:/www.thieme-connect.com/products/ejournals/abstract/10.1055/s-004 0-1715101.

10. Ehmke T, Aghazadeh M, Bono OJ, Robbins C, Bono JV. Anthropometric measures of the posterior condyles: gender differences and correlation to implant sizing. J Knee Surg. 2019;34(07):679-84. https://doi.org/10.1055/s0039-1700823.

11. Xie X, Lin L, Zhu B, Lu Y, Lin Z, Li Q. Will gender-specific total knee arthroplasty be a better choice for women? A systematic review and metaanalysis. Eur J Orthop Surg Traumatol. 2014;24(8):1341-9. https://doi.org/10.1 007/s00590-013-1396-6.

12. Chung BJ, Kang JY, Kang YG, Kim SJ, Kim TK. Clinical implications of femoral anthropometrical features for Total knee Arthroplasty in Koreans. J Arthroplast. 2015;30(7):1220-7. https://doi.org/10.1016/j.arth.2015.02.014

13. Fehring TK, Odum SM, Hughes J, Springer BD, Beaver WB Jr. Differences between the sexes in the anatomy of the anterior condyle of the knee. JBJS. 2009;91(10):2335-41. https://doi.org/10.2106/JBJS.H.00834.

14. Mensch JS, Amstutz HC. Knee morphology as a guide to knee replacement. Clin Orthop Relat Res. 1975;112(1):231-41. https://doi.org/10.1097/00003 086-197510000-00029.

15. Mahfouz M, Abdel Fatah EE, Bowers LS, Scuderi G. Three-dimensional morphology of the knee reveals ethnic differences. Clin Orthop Relat Res. 2012;470(1):172-85. https://doi.org/10.1007/s11999-011-2089-2.

16. Kim TK, Phillips M, Bhandari M, Watson J, Malhotra R. What differences in morphologic features of the knee exist among patients of various races? A systematic review. Clin Orthop Relat Res. 2017;475(1):170-82. https://doi. org/10.1007/s11999-016-5097-4

17. Li P, Tsai TY, Li JS, Zhang Y, Kwon YM, Rubash HE, et al. Morphological measurement of the knee: race and sex effects. Acta Orthop Belg. 2014; 80(2):260-8.

18. Mohan H, Chhabria P, Bagaria V, Tadepalli K, Naik L, Kulkarni R. Anthropometry of nonarthritic Asian knees: is it time for a race-specific knee implant? Clin Orthop Surg. 2020;12(2):158-65. https://doi.org/10.4055/cios19069.

19. Chaichankul C, Tanavalee A, Itiravivong P. Anthropometric measurements of knee joints in Thai population: correlation to the sizing of current knee prostheses. Knee. 2011;18(1):5-10. https://doi.org/10.1016/j.knee.2009.12.005. 
20. Lim HC, Bae JH, Yoon JY, Kim SJ, Kim JG, Lee JM. Gender differences of the morphology of the distal femur and proximal tibia in a Korean population. Knee. 2013;20(1):26-30. https://doi.org/10.1016/j.knee.2012.05.010.

21. Cheng FB, Ji XF, Lai Y, Feng JC, Zheng WX, Sun YF, et al. Three dimensional morphometry of the knee to design the total knee arthroplasty for Chinese population. Knee. 2009;16(5):341-7. https://doi. org/10.1016/j.knee.2008.12.019.

22. McNamara CA, Hanano AA, Villa JM, Huaman GM, Patel PD, Suarez JC Anthropometric measurements of knee joints in the Hispanic population. J Arthroplast. 2018;33(8):2640-6. https://doi.org/10.1016/j.arth.2018.03.052.

23. Hafez MA, Sheikhedrees SM, Saweeres ES. Anthropometry of Arabian arthritic knees: comparison to other ethnic groups and implant dimensions. J Arthroplast. 2016;31(5):1109-16. https://doi.org/10.1016/j.arth.2015.11.017.

24. Heidari B. Knee osteoarthritis prevalence, risk factors, pathogenesis and features: part I. Caspian J Intern Med. 2011:2(2):205-12.

25. Kwak DS, Surendran S, Pengatteeri YH, Park SE, Choi KN, Gopinathan P, et al. Morphometry of the proximal tibia to design the tibial component of total knee arthroplasty for the Korean population. Knee. 2007;14(4):295-300. https://doi.org/10.1016/j.knee.2007.05.004.

26. Uehara K, Kadoya Y, Kobayashi A, Ohashi H, Yamano Y. Anthropometry of the proximal tibia to design a total knee prosthesis for the Japanese population. J Arthroplast. 2002;17(8):1028-32. https://doi.org/10.1054/arth.2 002.35790

27. Loures FB, Carrara RJ, Goes RFA, Albuquerque R, Barretto JM, Kinder A, et al. Anthropometric study of the knee in patients with osteoarthritis: intraoperative measurement versus magnetic resonance imaging. Radiol Bras. 2017;50(3):170-5. https://doi.org/10.1590/0100-3984.2016.0007.

28. Hofmann AA, Evanich JD, Ferguson RP, Camargo MP. Ten- to 14-year clinical followup of the cementless natural knee system. Clin Orthop Relat Res. 2001;388:85-94. https://doi.org/10.1097/00003086-200107000-00013.

29. Song SJ, Detch RC, Maloney WJ, Goodman SB, Huddleston JI 3rd. Causes of instability after total knee arthroplasty. J Arthroplast. 2014;29(2):360-4. https://doi.org/10.1016/..arth.2013.06.023.

30. Hitt K, Shurman JR 2nd, Greene K, McCarthy J, Moskal J, Hoeman T, et al. Anthropometric measurements of the human knee: correlation to the sizing of current knee arthroplasty systems. J Bone Joint Surg Am. 2003;85-A(Suppl 4):115-22.

31. Bracey DN, Brown ML, Beard HR, Mannava S, Nazir OF, Seyler TM, et al. Effects of patellofemoral overstuffing on knee flexion and patellar kinematics following total knee arthroplasty: a cadaveric study. Int Orthop. 2015;39(9):1715-22. https://doi.org/10.1007/s00264-015-2715-9.

32. Kawahara S, Matsuda S, Fukagawa S, Mitsuyasu H, Nakahara H, Higaki H, et al. Upsizing the femoral component increases patellofemoral contact force in total knee replacement. J Bone Joint Surg Brit. 2012;94(1):56-61. https://doi.org/10.1302/0301-620X.94B1.27514.

33. Mahoney OM, Kinsey T. Overhang of the femoral component in total knee arthroplasty: risk factors and clinical consequences. J Bone Joint Surg Am. 2010:92(5):1115-21. https://doi.org/10.2106/JBJS.H.00434.

34. Simsek ME, Akkaya M, Gursoy S, Isik C, Zahar A, Tarabichi S, et al. Posterolateral overhang affects patient quality of life after total knee arthroplasty. Arch Orthop Trauma Surg. 2018;138(3):409-18. https://doi.org/1 0.1007/s00402-017-2850-4.

\section{Publisher's Note}

Springer Nature remains neutral with regard to jurisdictional claims in published maps and institutional affiliations.

Ready to submit your research? Choose BMC and benefit from:
- fast, convenient online submission
- thorough peer review by experienced researchers in your field
- rapid publication on acceptance
- support for research data, including large and complex data types
- gold Open Access which fosters wider collaboration and increased citations
- maximum visibility for your research: over 100M website views per year
At BMC, research is always in progress.
Learn more biomedcentral.com/submissions

